\title{
The Effect of Disaster Management Education on Mother's Under Five Preparedness Facing Floods In Aceh Province
}

\author{
Rachmawati Rachmawati*, Rosi Novita, Ida Fitria \\ Department of Nutrition, Polytechnic of Health, Ministry of Health, Aceh, Indonesia
}

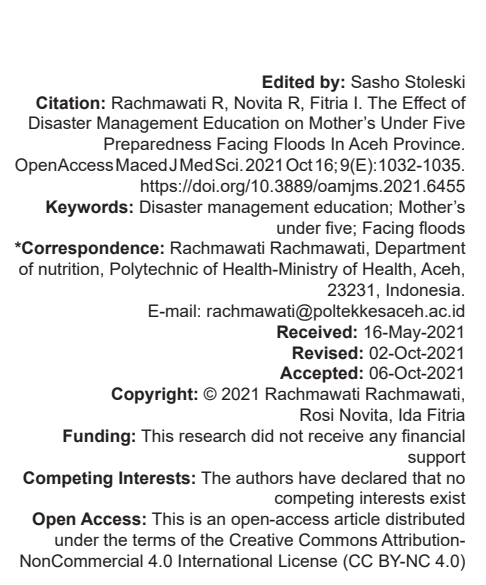

Introduction

World disaster statistics show that hydrological disasters, namely floods and landslides, are the most significant disasters globally at $51.7 \%$ [1]. In 2016, Indonesia experienced the second-highest hydrological disaster after China. Losses caused by hydrological disasters amounted to the US $\$ 59$ billion, and deaths reached 5 thousand people/year, especially from flash floods [2]. The World Bank reports that Indonesia is ranked $12^{\text {th }}$ globally for the risk of death from more than one disaster threat. Flood is one of the disasters that often occurs in Indonesia. According to BNPB, flooding is an event or condition in which an area of land is submerged due to the increased volume of water. Based on the results of a disaster risk study compiled by BNPB in 2017, the number of people at risk of flooding is spread across several islands with a total of more than 170 million people and an asset value of more than IDR 750 trillion. BNPB data (2018) for 2006-2016 shows that there have been 6864 flood events in Indonesia and $6.5 \%$ of them are flash floods [3]. Communities affected by the flood experience life-threatening losses. Alternative efforts are needed to reduce the impact of disasters, one of which is Disaster Management Education. Lack of a proper disaster management process creates ineffective response measures [4]. The disaster management process begins by identifying risks that may impact communities, families, individuals, and hospitals [5]. Disaster education includes many aspects, for example, the introduction of potential disasters in the vicinity, the history of disasters that have occurred, forms of anticipation, increasing awareness of signs of disaster, the impact of disasters on individuals, families, and communities, ways of handling in disaster conditions, and how to save themselves from disasters. Preparedness and understanding of the importance of adaptation efforts to face disasters are still low in Indonesia [6].

The knowledge of local communities to deal with disasters has different characters and methods according to the experiences of each region. Every practice of disaster management based on local knowledge of a community continues to develop and become input for building community resilience[7]. Communities can be resilient if they can organize themselves in increasing their capacity to learn from disasters and reduce risk factors arising from 
disasters [8]. Improving the capacity of a community after a disaster is an essential part of how to adjust before, during, and after a disaster. Community preparedness needs to be seen as an actual effort, especially for vulnerable groups. Vulnerable groups need special treatment and protection in order to survive post-disaster situations.

Several studies stated that many victims of natural disasters were caused by the victims not knowing the threat [9]. Women are considered a vulnerable group and face many problems during disasters [10]. Increasing the capacity of vulnerable communities is essential to reduce the impact of natural disasters before a disaster occurs, including long-term disaster risk reduction preparedness and actions. Mothers under five are one of the most vulnerable groups during a disaster. During a disaster, mothers under five often experience difficulties providing support to children under five who are also vulnerable groups. Therefore, it is important to provide disaster education for vulnerable groups such as mothers of children under five. The purpose of this study is to analyze the effect of education on flood disaster preparedness in Acehnese society.

\section{Methods}

This study used a quasi-experimental study with a One-Group Pretest-Posttest design. In the design before and after treatment in education or education, the dependent variable was measured using pretest and posttest questionnaires. This research will be carried out in the West Aceh district with the location of village Napai and in Aceh Besar district with the seulimum location. Both locations are areas that often experience flooding. The research was carried out from November to December 2020. The population in this study were all mothers of children under five in village Napai and Seulimum village. The independent variable in this study is the knowledge, attitudes, and preparedness of the mothers under five, while the dependent variable is disaster education. Disaster education is carried out for 3 months at the research location. Data collection on the preparedness of mothers under five in this study was carried out using pretest and posttest questionnaires before and after the provision of disaster education. Data analysis was performed by univariate, bivariate. Analysis was used to determine the distribution of each variable (frequency distribution, mean, and standard deviation), while bivariate analysis used dependent t-test and relationship analysis used Spearman Rank correlation.

\section{Results}

\section{Sample characteristics}

The sample in this study were all mothers who have children under five, as many as 51 people. Fiftynine mothers have toddlers in Napa village, but only 51 mothers with toddlers who attended the education or training activities were present. The following are the characteristics of mothers under five who were sampled in this study (Table 1):

Table 1: Characteristics of the mother of a toddler

\begin{tabular}{lll}
\hline Variable & $\mathrm{F}$ & $\%$ \\
\hline Age & 40 & 78 \\
$20-35$ years & 11 & 22 \\
$\quad>35$ years & & \\
Educaton & 27 & 53 \\
$\quad$ Primary & 20 & 39 \\
Secondary & 4 & 8 \\
$\quad$ Higher & 46 & 90 \\
Occopation & 5 & 10 \\
$\quad$ Employed & Unemployed & \\
\hline
\end{tabular}

Most of the sample was between 20 years and 35 years old, namely $78 \%$, where the youngest sample age was 22 years, and the oldest was 40 years. Most of the latest education samples are at the primary school (SD) level, namely $52 \%$, and as many as $40 \%$ of the sample work to help their husbands as farmers, while $60 \%$ of the mothers of the sample under five do not work or only take care of the household.

Table 2: Knowledge of mother toddlers before and after education

\begin{tabular}{llllll}
\hline Knowledge & $\mathrm{n}$ & Mean (std.deviasi) & $\mathrm{t}$ & $\mathrm{df}$ & Sig. (2- tailed) \\
\hline Before & 51 & $89.45(11.29)$ & -4.475 & 50 & 0.000 \\
After & 51 & $94.53(5.19 \mathrm{Z})$ & & & \\
\hline $\mathrm{p}<0.05$. & & & & &
\end{tabular}

\section{Toddler mother knowledge}

The results of the measurement of the pre-test and post-test scores on the knowledge of the mothers under-fives, it is known that the knowledge of mothers under five about disasters is quite good, with an average pre-test result of 89.45. After giving education, there was an increase in the average knowledge of mothers under five to 94.53 (Table 2).

Table 3: Attitudes of toddlers before and after education

\begin{tabular}{llllll}
\hline Attitude & $\mathrm{n}$ & Mean (std.deviasi) & $\mathrm{t}$ & $\mathrm{df}$ & Sig. (2- tailed) \\
\hline $\begin{array}{l}\text { Before } \\
\text { After }\end{array}$ & 51 & $39.43(9.42)$ & -6.628 & 50 & 0.000 \\
\hline $\mathrm{p}<0.05$. & 51 & $47.71(4.22)$ & & & \\
& The & results of statistical tests using the
\end{tabular}
dependent t-test were obtained $(p<0.05)$, which means that there can be significant differences in mothers' knowledge under five about disasters before and after the provision of education. On average, the mother is already good at knowledge before providing education because the mother was used to disasters, and some mothers under five stated that they had received information about disasters. Another factor that affects 
Table 4: Preparedness of toddlers before and after education

\begin{tabular}{llllll}
\hline Preparedness & $\mathrm{N}$ & Mean (std.deviasi) & $\mathrm{t}$ & $\mathrm{df}$ & Sig. (2- tailed) \\
\hline Before & 51 & $50.69(10.15)$ & -5.963 & 50 & 0.000 \\
After & 51 & $58.82(3.55)$ & & & \\
\hline $\mathrm{p}<0.05$. & & & & &
\end{tabular}

the level of knowledge in dealing with disasters which can increase awareness to prevent a more significant impact from a disaster event, was essential [11].

\section{The attitude of the mother of a toddler}

The results of the pre-test and post-test scores on the attitudes of the toddler's mother show that the average of the mothers of the toddlers before being given education is 39.43 . The average value of mothers' attitudes in facing disasters after receiving education has increased 47.71 (Table 3).

The t-dependent test results show that there are significant differences in mothers' attitudes in dealing with disasters before and after receiving education for mothers of children under five $(p=0.000)$. Knowledge plays a vital role for someone in determining attitudes. An increase in knowledge supported by education and experience about disasters will impact attitudes toward what is done in the face of disasters (Notoadmojo, 2007). Knowledge influences the level of disaster preparedness in Acehnese rural communities.

\section{Toddler mother preparedness}

Preparedness is the basis for active disaster risk reduction efforts before a disaster. Disaster preparedness must be measured so that the community's level of preparedness can be found in facing the possibility of a disaster in their environment. The pre-test and post-test scores on the preparedness of the mothers of children under five were known that before being given education, it was already good, namely, 50.69, while the average value of maternal preparedness increased after being given education, namely 58.82 (Table 4).

The t-dependent test results showed a significant difference in the value of maternal preparedness before and after receiving education about disasters and maternal preparedness of children under five $(p=0.000)$. This study indicates that education about disasters and preparedness is needed, especially for disaster-prone groups and people in disaster-prone locations. Education and experience are factors that influence the level of preparedness in facing disasters. Awareness of disaster risks, both knowledge and potential impacts and losses due to disasters can also affect the level of disaster preparedness [12]. Rural communities often experience floods, so that people or mothers under five also have a pretty good level of preparedness. disaster preparedness is critical to ensuring frontline health workers can respond effectively to disaster events [13].

\section{Discussion}

The flood disaster has caused various impacts on people in Aceh. The results showed a significant difference in the mean value of knowledge, attitudes, and preparedness of under-five mothers before and after receiving education about disasters, as evidenced by statistical tests using the dependent $\mathrm{t}$-test with a $p<0.05$. Disaster management education has improved knowledge, attitudes, and community preparedness in the research location. The community considers disaster management education to have provided much knowledge on how to adapt and minimize impacts. Disaster education for women can increase the level of education, awareness, and readiness of all family members, especially children [14]. Knowledge, skills, and disaster preparedness require continuous strengthening to increase self-efficacy in disaster management [15]. Disaster education aims to provide knowledge to individuals and groups to reduce vulnerability to disasters (torani). Disaster experiences will be a helpful lesson in the future for mothers of toddlers. This can be seen when a disaster occurs, so the individual who experiences, of course, has his trauma. The trauma experienced will provide a response and learning to make it as information. The information obtained will result in an action that must be taken when the flood disaster occurs again. Knowledge, skills, and disaster preparedness require continuous strengthening to increase self-efficacy in disaster management [16]. Knowledge is the result of constant observations because it does not provide critical assessment and testing by others. Thus it is not systematic and objective and is not universal [17]. The most crucial learning process relates to the experiences gained in how to prepare for and live with floods [18]. One of the things that affect community resilience is adaptive capacity, which is the ability of the community to adapt to changes due to disasters, consisting of institutional memory, innovative learning, and connectedness [19]. Disaster management education is expected to be a helpful experience that will influence behavior in the future to become a lesson. Every flood disaster experience provides the possibility to prepare themselves in anticipation of threats that can occur at any time. Measures must be taken in the event of a disaster in a fast and effective manner. The level of community resilience is an essential step for developing strategies and taking actions to achieve disaster resilience in the community and to manage the skill of disaster risk reduction [20]. Community-government relations have a significant impact on the formation of internal community ties (bonding) and also intercommunity relations (bridging) so that it dramatically affects the progress of a social association [21]. Continuous disaster training that integrates learning needs is needed to achieve effective disaster preparedness and management at the community 
level [22]. Nevertheless, it needs to be understood that even though the community already has the knowledge to deal with floods, not all of them are ready to face disasters and adapt themselves to post-disaster situations. After a flood occurs, some individuals will experience excessive fear and anxiety, avoid disasterrelated things, recall disaster events, deep sadness, emotional numbness, and psychosomatic symptoms.

\section{Conclusion}

The mothers of toddlers have sufficient knowledge, attitudes, and preparedness in dealing with floods. There is a significant difference in the average value of knowledge, attitudes, and preparedness of under-five mothers before and after receiving education about disasters.

\section{References}

1. Guha-Sapir D, Hoyois P, Below R. Annual Disaster Statistical Review 2011: The Numbers and Trends. Belgium: Centre for Research on the Epidemiology of Disasters (CRED); 2012.

2. French J, Ing R, von Allmen S, Wood R. Mortality from flash floods: A review of national weather service reports, 1969-81. Public Health Rep. 1983;98(6):584-8.

PMid:6419273

3. DIBI. Data Informasi Bencana Indonesia; 2019.

4. Zarzosa MD, Tibaduiza ML, Jaramillo N. Disaster Risk Reduction: A Decision-Making Support Tool Based on the Morphological Analysis; 2020.

5. Hammad KS, Arbon P, Gebbie KM. Emergency nurses and disaster response: An exploration of South Australian emergency nurses' knowledge and perceptions of their roles in disaster response. Australas Emerg Nurs J. 2011;14(2):87-94. https://doi.org/10.1016/j.aenj.2010.10.002

6. Martono M, Satino S, Nursalam N, Efendi F, Bushy A. Indonesian nurses' perception of disaster management preparedness. Chin J Traumatol. 2019;22(1):41-6. https://doi.org/10.1016/j. cjtee.2018.09.002

PMid:30850325

7. Cutter SL, Finch C. Temporal and spatial changes in social vulnerability to natural hazards. Proc Natl Acad Sci. 2008;105(7):2301-6.
8. Novianty A. Penyesuaian dusun jangka panjang ditinjau dari resiliensi komunitas pasca gempa. J Psikol. 2011;38(1):30-9.

9. Febriana DS, Abubakar Y. Disaster preparedness village community in facing disasters in Meuraxa district, Banda Aceh city. J Ilmu Kebencanaan. 2015;2(3):41-9.

10. Fox L, Timm N. Pediatric issues in disaster preparedness: Meeting the educational needs of nurses-are we there yet? J Pediatr Nurs. 2008;23(2):145-52. https://doi.org/10.1016/j. pedn.2007.12.008 PMid: 18339341

11. Hoffmann R, Muttarak R. Learn from the past, prepare for the future: Impacts of education and experience on disaster preparedness in the Philippines and Thailand. World Dev. 2017;96:32-51. https://doi.org/10.1016/j.worlddev.2017.02.016

12. Notoatmodjo S. Promosi Kesehatan dan IImu Perilaku. Vol. 20. Jakarta: Rineka Cipta; 2007.

13. Husna C, Hafni M, Fithria F, Jannah SR. The Effectiveness of Disaster Mitigation Education on Earthquake and Tsunami Disaster Preparedness in the Families of Inpatients at Hospital. Idea Nurs J. 2019;10(1):21-6.

14. Usher K. Are We Ready? Preparing Nurses to Respond to Disasters and Emerging Infectious Diseases; 2010.

15. O'Brien G, O'Keefe P, Rose J, Wisner B. Climate change and disaster management. Disasters. 2006;30(1):64-80. https://doi. org/10.1111/j.1467-9523.2006.00307.x PMid:16512862

16. Al Khalaileh MA, Bond E, Alasad JA. Jordanian nurses perceptions of their preparedness for disaster management. Int Emerg Nurs. 2012;20(1):14-23. https://doi.org/10.1016/j. ienj.2011.01.001

PMid:22243713

17. Nasdian FT. Pengembangan Masyarakat. Jakarta: Yayasan Pusaka Obor Indonesia; 2014.

18. Hooli LJ. Resilience of the poorest: Coping strategies and indigenous knowledge of living with the floods in Northern Namibia. Reg Environ Change. 2016;16(3):695-707. https://doi. org/10.1007/s10113-015-0782-5

19. Longstaff $\mathrm{PH}$, Armstrong NJ, Perrin K, Parker WM, Hidek MA Building resilient communities: A preliminary framework for assessment. Homel Secur Aff. 2010;6(3):1-23.

20. Yoon DK, Kang JE, Brody SD. A measurement of community disaster resilience in Korea. J Environ Plan Manage. 2016;59(3):436-60

21. Szreter, S. Rethinking McKeown: The relationship between public health and social change. Am J Public Health. 2002;92(5):722-5. https://doi.org/10.2105/ajph.92.5.722 PMid:11988434

22. Sangkala MS, Gerdtz MF. Disaster preparedness and learning needs among community health nurse coordinators in South Sulawesi Indonesia. Australas Emerg Care. 2018;21(1):23-30. https://doi.org/10.1016/j.auec.2017.11.002 PMid:30998861 